\title{
GENDER DIFFERENCES IN PERCEPTION ON SUSTAINABLE TOURISM - CASE STUDY APPLIED TO THE PU IN PREŠOV
}

\author{
Anna ŠENKOVÁ* \\ The University of Prešov, Faculty of Management, Department of Tourism \\ and Hotel Management, Konštantínova 16,080 01 Prešov, Slovakia, e-mail: anna.senkova@unipo.sk
}

Roman VAVREK

The University of Prešov, Faculty of Management, Department of Management,

Konštantínova 16,080 01 Prešov, Slovakia, e-mail: roman.vavrek@yahoo.com

\author{
Natália MOLNÁROVÁ \\ The University of Prešov, Faculty of Management, Department of Tourism \\ and Hotel Management, Konštantínova 16, 08001 Prešov, Slovakia, e-mail: natalia.nmolnarova@gmail.com
}

\section{Jana MITRÍKOVÁ}

The University of Prešov, Faculty of Management, Department of Tourism

and Hotel Management, Konštantínova 16,080 01 Prešov, Slovakia, e-mail: jana.mitrikova@unipo.sk

\begin{abstract}
Citation: Šenková, A., Vavrek, R., Molnárová, N., \& Mitríková, J. (2020). GENDER DIFFERENCES IN PERCEPTION ON SUSTAINABLE TOURISM - CASE STUDY APPLIED TO THE PU IN PREŠOV. GeoJournal of Tourism and Geosites, 32(4), 1216-1221. https://doi.org/10.30892/gtg.32404-560
\end{abstract}

\begin{abstract}
Sustainable tourism is the concept of travelling and discovering destinations in which the visitor takes full account and respect to the culture, environment and community of a visiting country. The awareness of the increasing global problems related to the environment leads to the change of the consumer behaviour. The aim of the article is to present results of the analysis which was focusing on evaluating the perception of the concept of sustainable tourism. Furthermore, this article identifies the attitudes towards this concept and difference s in opinions between genders, among the students of the University of Prešov. The primary source of information was obtained through a questionnaire survey, which sample consisted of 460 students out of which $58.04 \%$ were women and $41.96 \%$ were men. The questionnaire was processed and evaluated in the MS Excel, Statistica 13.4 and Statgraphics XVIII using Kolmogorov-Smirnov test, Mann-Whitney test, Kendall rank correlation coefficient. The final results showed that students of the University of Prešov perceive a negative demand of sustainable touris $m$ in Slovakia. In every statement related to sustainable tourism, men showed a more negative approach than women. Slighter different opinion among men and women were noticed in the willingness to financially support the development of sustainable tourism.
\end{abstract}

Key words: sustainability, sustainable tourism, consumer behaviour, young travellers

\section{INTRODUCTION}

Over the last decades, countries became aware that, the current unregulated development and growth of the world economy is unsustainable. In the conditions of market economy all business entities, which can be viewed as socio-economic systems must be competitive (Ivaničková et al., 2016). For the humanity to continue its existence, the society realized the necessity to crea te conditions and promote sustainable development, which is the assumption for maintaining a healthy environment. Also, quality of life is directly influenced by the quality of the environment. Environmental quality is influenced by various factors, mainly by anthropogenic activities (Huttmanová et al., 2013). Tourism in many countries creates an important economic share by providing job, new business oppor tunities which leads to an increased GDP. Sustainable tourism takes full account of the current and future economic, social and environmental impacts, while meeting the needs for both visitors and hosts while improving opportunities for future generations. It is assumed that sustainable tourism leads to managing resources in a way that the economic, social and aesthetic needs are fulfilled while cultural authenticity, basic ecological processes, biological diversity and environmental support system is preserved. The fundamentals of sustainability include environmental, economic and socio-cultural aspects. To maintain the long-term sustainability, appropriate balance must be between these tree aspects (United Nations Environment Programme and World Tourism Organization, 2005). However, there is no clear answer to whether tourism can achieve an ideal balance where on one hand a country is economically growing and benefitting while on the other hand respecting, protecting and enhancing the environment and the quality of the life of domestic people.

Sustainable tourism is often confused with environmental, ecological or green tourism. However, sustainable tourism is a wider term, which covers not only the protection of natural, environmental and ecological resources, but also focuses on the economic and social aspects which it helps to develop. As an important part of sustainable development is also the implementation of environmental education at every level of education. Education about sustainable development should primarily focus on how to develop the environmental awareness and raising students' knowledge of the economic aspects of environmental protection. University graduates should unconditionally receive adequate knowledge and information about climate changes uncontrolled economic development. There must be fundamental approaches to a high quality of education for sustainable development. College and university alumni are favourable places not only for educational purposes but also can serve for scientific and research institutions for sustainable development.

\section{Theoretical Background}

Sustainable development is one of the most current topics both in theory and practice. The concept of Sustainability and Sustainable

\footnotetext{
* Corresponding author
} 
Development was launched in 1987 at the First World Summit in Stockholm (United Nations Conference on Human Environment) by the United Nation World Commission on Environment. The result was the Brundtland Report document (Black, 2012). In particular, report of the World Commission on Environment and Development, (the document came to be known as "the Brundtland Report"), defined the concept of 'sustainable development' as the development that meets the needs of today's generation without threatening the future generations (United Nations, 1987). Second World Summit on Sustainable Development and environment, United Nations Conference on Environment and Development, took place in Rio de Janeiro in 1992. The resulting documents were:

- Framework Convention on Climate Change;

- Convention on the maintaining of natural biodiversity;

- Declaration on the Environment and Development,

-Agenda 21 for the travel \& tourism industry: towards environmentally sustainable development universal care for the environment on Earth with a view of the 21 st century

- Principles on the use, protection and sustainable development of all types of forests (United Nations, 2012).

The World Summit on Sustainable Development (WSSD) was held in Johannesburg in 2002 to review progress since the Rio conference in 1992, and to agree a new global deal on sustainable development. Unlike its predecessor, it was primarily concerned with implementation rather than with new treaties and targets, although a number of new targets were agreed, for example one on sanitation. Health was singled out as one of five priority areas, along with water, energy, agriculture and biodiversity. Failure to agree a target on renewable energy was regarded as a major disappointment of the conference (von Schirnding, 2005).

The United Nations Conference on Sustainable Development Rio +20 was held again in Rio de Janeiro, Brazil in 2012 (United Nations Department of Economic and Social Affairs, 2012). The resulting document outlined practical arrangements for its implementation in national policies. The conference adopted basic regulations on green economy policies, a strategy for financing sustainable development, a policy forum for sustainable development. The United Nations Statistical Commission was asked to launch a program of measures to check if the political decisions of the entities were in line with the rules for sustainable development.

The message of the conference was: "The future we want".

The main document launched of this conference was A / CONF.216/5 containing a 10-year program with models for sustainable production and consumption patterns (United Nations, 2012). It contained the steps necessary to put these methods into practice. Rio +20 has also taken future decisions, including energy, food security, ocean and urban pollution. The last Sustainable Development Summit was held at the UN headquarters in New York in September 2015. More than 150 world leaders adopted the "Global Goals for Sustainable Development" program and the 2030 Agenda for Sustainable Development, valid for 2015-2030. Agenda 2030's message is " By people, from people, to people". This document is the source document for international communities and national governments. Business, connected to Agenda 2030 concentrates not only on achieving the quantity of the objectives that are set, but in particular, quality of the objectives. Agenda 2030 for sustainable development is the most comprehensive document of global priorities so far, consisting of 17 main objectives elaborated into 169 partial objectives (Statistical Office of the Slovak Republic, 2018).

The beginnings of scientific research in terms of sustainable development, date back to the 1980s. At that time, the International Organization of UNESCO launched the program "Man and the Biosphere" which evaluated how tourism influenced the territory of the Alps over the past 100 years. The conclusion of the study contains the principles of the sustainable development of tourism, which must be applied not only in the Alps, but everywhere in the world. At that time, the need to move from mass to sustainable tourism development was asserted. Also based on the results of the study, Krippendorf (1987) published a pioneering study entitled Alpsegen - Alptraum, which advocates that tourism in the Alps was developed in accordance with the principles of sustainable development. His theme became interesting in theory and practice and caused the development of the relationship between tourism and sustainable development.

In 1996, the World Tourism Organization (UNWTO), the World Tourism Council (WTTC) and the Earth Council applied Agenda 21 to the conditions of tourism and published it under the title: Agenda 21 for the Travel \& Tourism Industry: Towards Environmentally Sustainable Development (UNEP 2003). Since 1999, tourism has been supplied to the third and fourth articles of the Global Code of Ethics for Tourism as a factor for sustainable development. Sustainable tourism is one of the approaches of the tourism sector, which should help make the best decisions in the tourism industry. They should be able to recognize its positive and negative benefits for the present and future population.

In addition to the initiatives of international organizations, the sustainable development of tourism is also addressed in theory. Its essence and importance are constantly explored by several authors who take into account various aspects.

In the 1990s, the authors paid particular attention to the general strategy and policy of sustainable tourism (Cronin, 1990; Bramwell and Lane, 1993; Butler, 1991; Hunter, 1997; Pigram, 1990; Swarbrooke, 1999). The focus of the study was on selected issues related to sustainable tourism development, namely the development of sustainable development indicators (Miller, 2001), the competitiveness of tourist destinations in terms of sustainable development (Ritchie and Crouch, 2003), an intercultural view of tourism and sustainable development (Robinson and Picard, 2006), surveying residents' attitudes to sustainable tourism (Choi and Murray, 2010). A team of researchers from the University of Applied Science and Arts Lucerne in Switzerland (R. Wehrli, H. Egli, M. Lutzenberger, D. Pfister, J. Schwarz and J. Stettler, 2011) in collaboration with the international travel agency Kuoni and the international consulting company IPK, conducted an international survey in 2011 entitled "Is there a demand for sustainable tourism?" The aim of the survey through 23 sustainability criteria divided into 3 areas - ecological, social and economic - was primarily to find out what factors influence the shopping behaviour of visitors when choosing a tourism product, how important the product sustainability is in choosing and buying a holiday destination and whether they are willing to pay more money for a sustainable product. The researches revealed that although none of the 23 criteria were preferred by the res pondents, more than $50 \%$ of them considered the socio-cultural criteria as the most relevant to sustainability, namely these criteria included the experience of visiting the destination, gaining cultural authenticity, visiting local landmarks. In connection with sustainable tourism, they considered it necessary to protect the cultural heritage, preserve and enhance the authenticity of the nation's culture. At the International Institute for Industrial Environmental Economics, Lund University Sweden, Budeanu (2007) conducted a survey entitled "Sustainable tourist behaviour a discussion of opportunities for change." The survey focused on the issues of sustainable tourism and passenger behaviour.

In her work, she dealt with the gaps between the positive attitude of passengers to sustainable tourism, but passive behaviour and irresponsible approach to this issue in practice. The research found that tourists behave irresponsibly towards ecology or local communities, thus not creating demand for sustainable tourism products. Low passenger support is one of the main obstacles to progress. One of the reasons may be lack of customer initiative or general ignorance. After identifying the gaps, it presents proposals such as increased awareness and awareness aimed at facilitating the transition to responsible and tourist behaviour (Budeanu, 2007). Professor J., I. Pulido-Fernández and Y. López-Sánchez (2016) at the University of Jaén Spain, the Department of Economics, authors of a case study "Are tourists willing to pay more for sustainable destinations? "were trying to find out if tourist would be eager to pay additional price 
for sustainable destinations. The results of the survey showed that tourists with greater knowledge about sustainability were willing to pay more for a sustainable destination. The results also showed that only $26.6 \%$ of respondents were willing to pay a higher amount money for a holiday destination if the contribution was used for the sustainable development of the destination. Out of the $26.6 \%$ of respondents, only $15 \%$ would to pay $20 \%$ more of the price they paid for their holiday destination in order to support a sustainable destination, the other $85 \%$ would pay up to $10 \%$ more to support sustainable destination. The authors presented two proposals .

One, was to increase the awareness about sustainability in order to change the patterns of the tourist's behaviour to furthermore support the willingness to pay a higher amount of money for sustainable destinations. The second proposal was to improve, inn ovate and promote existing products to further attract more and more people into this type of tourism. Both cases require strategic steps in supporting the demand and supply area, however involving public authorities and private companies would be necessary in order to secure this tourism with the law and knowledge-raising through advertising and promotion. After all, tourists' cooperation and conscious commitment to support sustainable tourism is the essence of success (Pulido-Fernandez and Lopéz-Sánchez, 2016). The question, how ecological education classes are integrated in the curriculum at pre-university level in Oradea, was to investigate in the research of a team of researchers from University of Oradea, Department of Geography, Tourism and Territorial Planning (Ilies at al., 2017).

Schwartz's $(1992,1994)$ classification of human values is applied when comparing a group of Finnish and Russian university students in terms of their environmentally and socially benign orientation, which is measured by including all three dimensions of sustainability in the measures of consumers' self-reported travelling preferences. A total of 872 responses were included in the data, which were analysed by using K-mean cluster analysis and a principal component analysis (PCA).

Differences between Finnish and Russian students were compared using independent samples t-test with equal variances assumed. The respondents divided evenly into two clusters, which could be named according to Schwarz as Self-Enhancers and Self-Transcenders. The majority of Finnish respondents $(67 \%)$ were Self-Transcenders, and among Russian students the majority were Self-Enhancers (84 $\%)$. The findings indicate that among the Russian students the concept of sustainability is understood as an ecological question, but for Finns, it is a comprehensive concept covering ecological, economic and social aspects. In the Finnish sample value based groups seemed to explain the sustainability concerns, but in the Russian sample, the value based group explained only the attitude towards ecological sustainability (Komppula et al., 2018). In recent years, the issue of overtourism has been increasingly discussed. Pasquinelii and Trunfio (2020) contribute to academic debate on overtourism by adopting a narrative approach to the analysis of how online news media represented it, stated its causes and effects, and suggested the actins to be taken for addressing it.

\section{MATERIAL AND METHODS}

Based on the theory presented in the previous chapters, sustainable tourism is a current issue of the $21^{\text {st }}$ century (see also Gallo et al., 2019). The answer, how to solve this issue all depends on the individuals' mentality, personality and many other factors rela ted to human activity. This case study focuses on evaluating the perception on the sustainable tourism concept from the PU students (university ranked as the $3^{\text {rd }}$ largest university in the Slovakia) point of view which belongs to the millennia's. The aim of the article is to identify att itudes and gender differences in the perception of sustainable tourism aspects in Central Europe. Data about the population, i. e. the amount of students, were collected from the Overview of Universities in Slovakia (CVTI SR, 2020). The total number of full-time students studying at the bachelor and master degree is 6060. The representative sample, consists of 460 students, who fully completed the questionnaire. The majority of respondents were women $(58.04 \%)$.

The questionnaire survey was carried out from 14 December 2018 to 14 March 2019 in several forms. In order to remain responsible towards the environment, the survey forms were handed out only in electronic form - GoogleDocs. Creating a QR code the questionnaire was available via social platforms such as Facebook, BeeTagg or QR APP. The questionnaire survey itself was preceded by a two-week pilot survey with 19 respondents.

The structure of the questionnaire is divided into 4 sections and precisely created from questions needed for analysing the issue. The beginning of the questionnaire includes identification questions which are followed by asking a direct question about what is understood by the concept of sustainable tourism. The respondents in the second section expressed their level of agreement or disagreement (on the scale of 1 to 5) with the statements related to sustainable tourism. In the third and fourth sections, the respondents expressed the degree of importance of selected factors and activities needed for sustainable tourism.

The conclusion of the analysis is formed mainly from the first and second section of the questionnaire, i.e. evaluating the perception of the sustainable tourism concept and its selected aspects, which were implemented through the following questions:

1. What do you understand under the concept of Sustainable tourism?

A. Traveling that meets the needs of tourists and preserves opportunities for future generations.

B. Traveling that minimizes negative impact on the environment.

C. Traveling that respects the culture, history, traditions and heritage of a host country.

D. Traveling that provides economic benefits, job opportunities for local residents and involves them in decision-making processes.

E. Traveling which is associated with active and passive participation in sport activities.

F. I do not know what sustainable tourism is.

2. Please select the degree of agreement with the following statements by choosing one of the following options (Likert scale 1-5):

I. In the country I currently live, there is a demand for sustainable tourism.

II. Protection of local heritage and tourism activities can be compatible.

III. Ecologically managed tourist destinations, preserved in their natural state, are more attractive for tourists.

IV. The local community should profit (financially, socially, economically) from tourism.

V. I am willing to contribute a financial amount to support the development of sustainable tourism (economic, social and environmental activities).

3. How much EUR would you be able to contribute to support sustainable tourism?

The questionnaire is processed and evaluated by using MS Excel, Statistica 13.4 and Statgraphics XVIII using a statistical formulas consisting of:

a) Kolmogorov-Smirnov test

$$
\begin{aligned}
D_{n_{2} n_{2}}= & \sup \left|F_{1, n_{1}}(x)-F_{2 n_{2}}(x)\right| \\
& -\infty<x<\infty
\end{aligned}
$$

where: $F_{1_{n}}(x)$ - empirical distribution function of first selection; 
$F_{2} n_{2}(x)$ - empirical distribution function of second selection.

b) Mann-Whitney test

$$
Q=n_{y} n_{x} \frac{n_{y}\left(n_{y}+1\right)}{2}-R_{y}
$$

where: $n_{x}$ - number of observations, resp. the extent of the $\mathrm{x}$-th file

$n_{y}$ - number of observations, resp. range of the y-th file

$R_{y}$ - the sum of the order of the y-th file

$\mathrm{U}, \mathrm{U}^{\prime}$ - test statistics

c) Kendall rank correlation coefficient

where: $n$ - number of observations of a pair of variables;

$$
r_{K}=\frac{n_{e}-n_{d}}{n(n-1) / 2}
$$

$n_{e}$ - the number of matching pairs of the pair;

$n_{d}$ - the number of mismatched pairs of the pair. For the theoretical background of selected tests/coefficients and their formulas see Cyhelský et al. (2001), Anděl (2007) or Pacáková et al. (2009).

\section{RESULTS AND DISCUSSION}

The result interpretation of the survey is divided in two parts. In the first part, the results are described using relative and absolute response rates. The second part of interpretation the results are analysed using the above described mathematical-statistical methods.

\section{Description of the results obtained}

The first step and as a part of evaluation was getting to know the understanding of the concept of "sustainable tourism", which directly determines the overall obtained results. The majority of respondents $(96.30 \%)$ chose one of the four offered interpretations of sustainable tourism. The largest group of respondents (32.83\%) understood the concept of sustainable tourism as traveling that meets the needs of tourists and preserves opportunities for future generations (i.e., Answer A), while the proportion of women in this group is more than double.

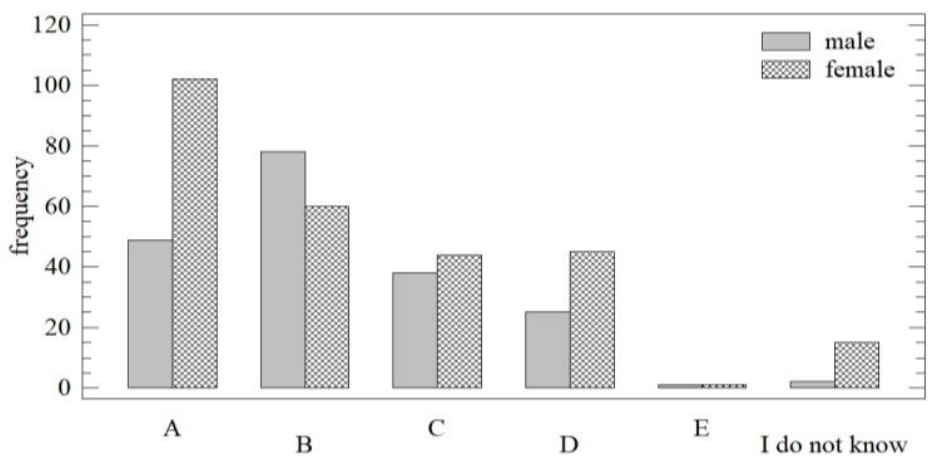

Figure1. Perception of the concept of sustainable tourism
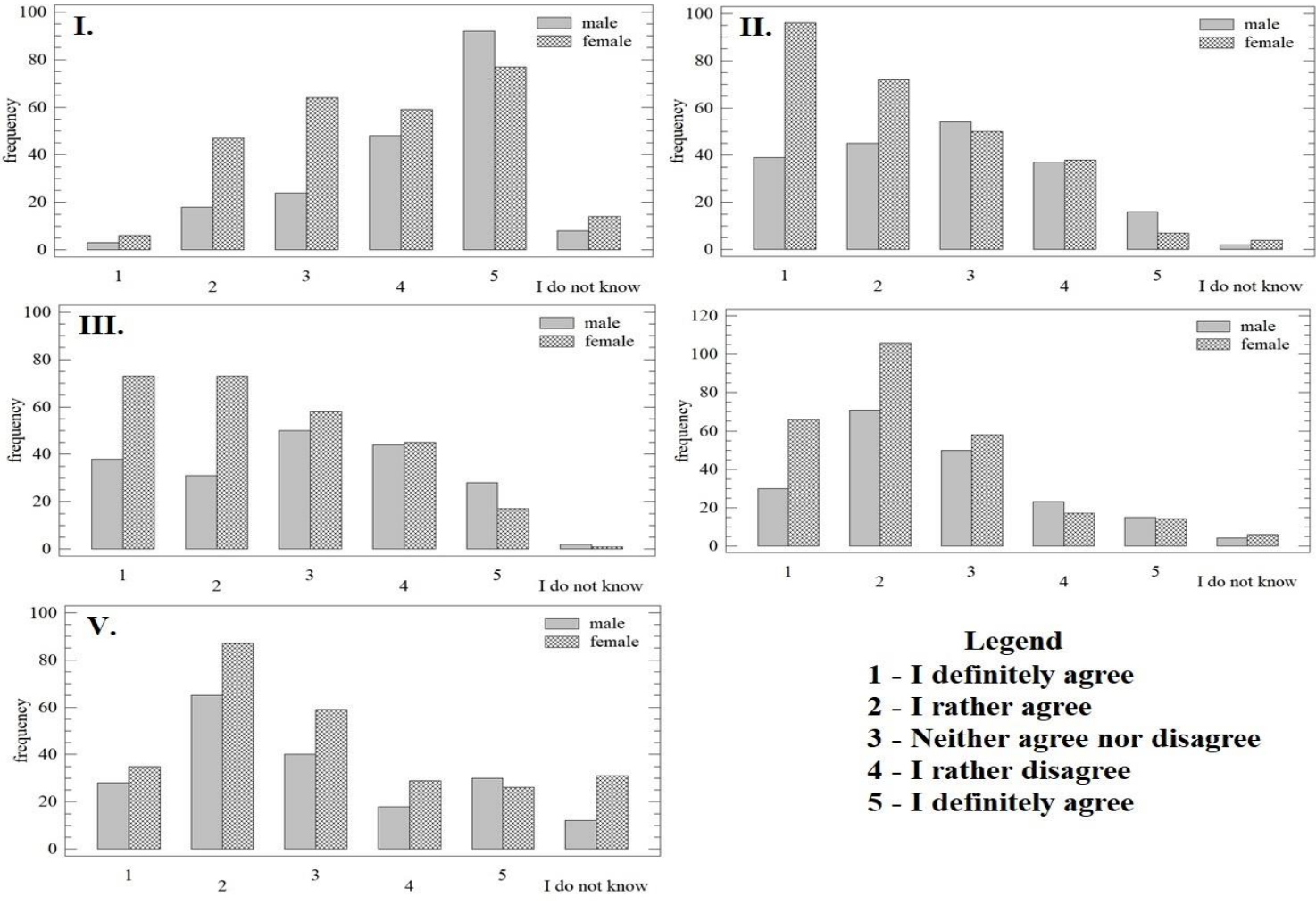

Legend

1 - I definitely agree

2 - I rather agree

3 - Neither agree nor disagree

4 - I rather disagree

5 - I definitely agree

Figure 2. The level of agreement to the statements 
The other three options, it is possible to observe the differences between the responses of men and women, which, however, are not as different as in the previous case (Figure 1). Interestingly, there is a significant female (15 to 2) predominance in the group of students who did not know what sustainable tourism is.

The first five statements, women evaluate the existence of demand for sustainable tourism in the country more positively than men. Almost half of men disagree with this statement (47.60\%), while only $4.7 \%$ of respondents were unable to define their point of view. We observe a more significant difference in the view of the protection of monuments and the support of tourism (statement II.), where rather women consider to be beneficial. Likewise, women perceive more positively the attractiveness of ecologically managed tourist destinations (statement III.), $99.35 \%$ of respondents were able to answer (457 out of 460).

The statement "the local community should profit from sustainable tourism" (statement IV.) is supported by an absolute majority of both men and women, while in the other categories we can see similar representation of both groups.

We can also observe a higher willingness of women to financially support the development of sustainable tourism (statement V). Figure 2 shows more detailed results and differences. The second part of the analysis concentrates on the statistical verification of the differences between men and women whereas the analysis does not include the answers of those respondents who were not able to give an opinion on individual statements, i.e. their answers can be described as 'I do not know'.

\section{Statistical evaluation of the obtained results}

The first step of the analysis compares the differences in the distribution function between the responses of men and women, which is also shown in Figure 3. Graphic differences were also demonstrated by the Kolmogorov-Smirnov test (e.g., $\left.D_{\text {I. }}=5,14 ; p<0,01\right)$, i.e. differences in the response structure of men and women can be considered statistically significant.
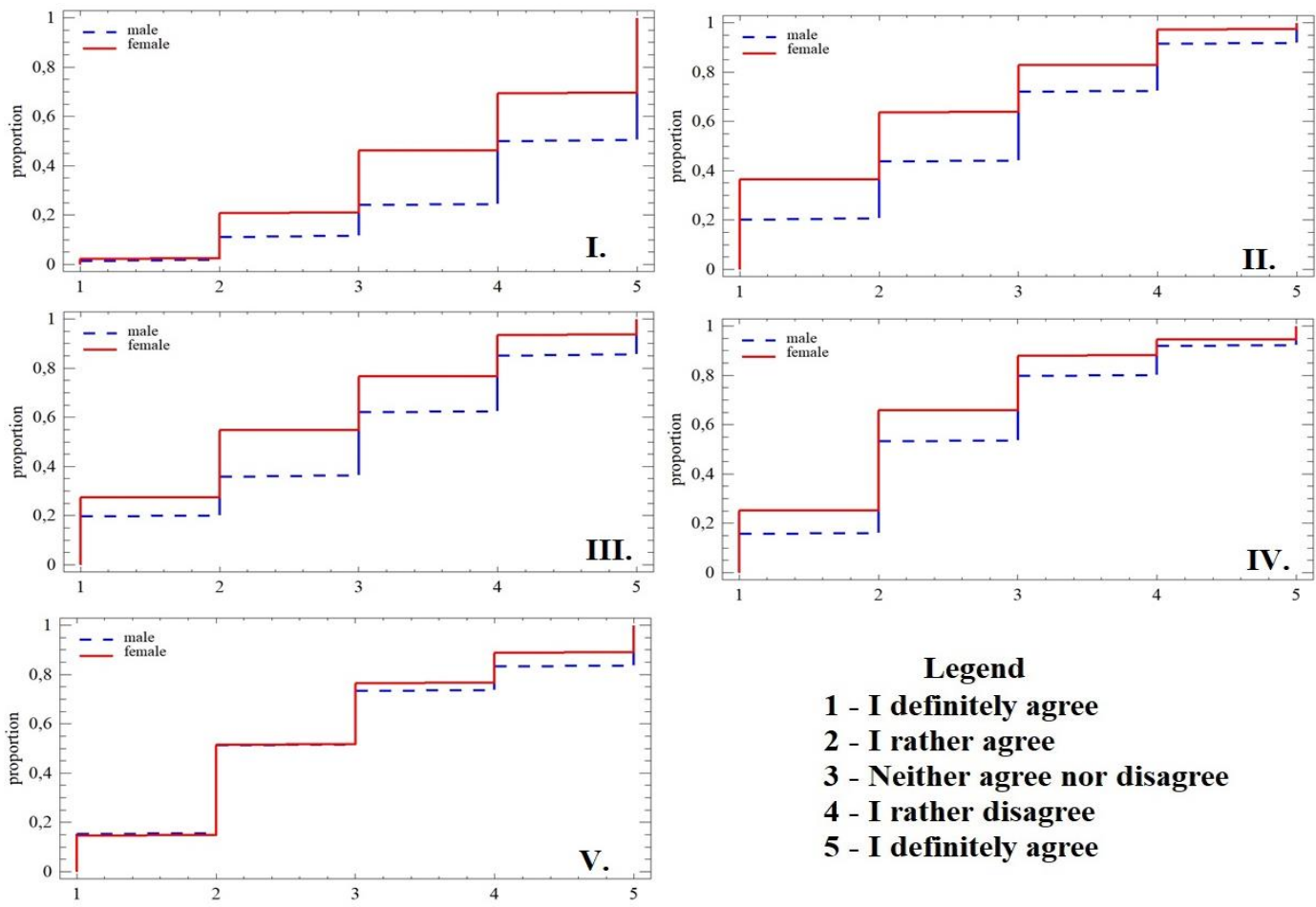

Legend

1 - I definitely agree

2 - I rather agree

3 - Neither agree nor disagree

4 - I rather disagree

5 - I definitely agree

Figure 3. Quantile plot of given statements

The distribution function of the first four statements also demonstrated significant differences in the mean value. In the statement $\mathrm{V}$, i.e. "the willingness to contribute a financial amount to support the development of sustainable tourism (economic, social and environmental activities) ", the median value is equal to 2 - I rather agree $(\mathrm{Q}=20854.5 ; \mathrm{p}=0.669)$. The differences in linear correlation of the opinions to every statements, i.e. their correlation, is shown in Figure 4. In both groups we observe 5 pairs of questions, while evaluation is significantly related. In the group of men, we determine small positive correlations e.g. a linear link between the existence of demand for sustainable tourism, and the mutual benefit of preserving monuments and promoting tourism. In the group of women, we observe a medium linear correlation in case of 3 pairs, which may bring greater benefits in other areas than men if one aspect of sustainable tourism is improved.
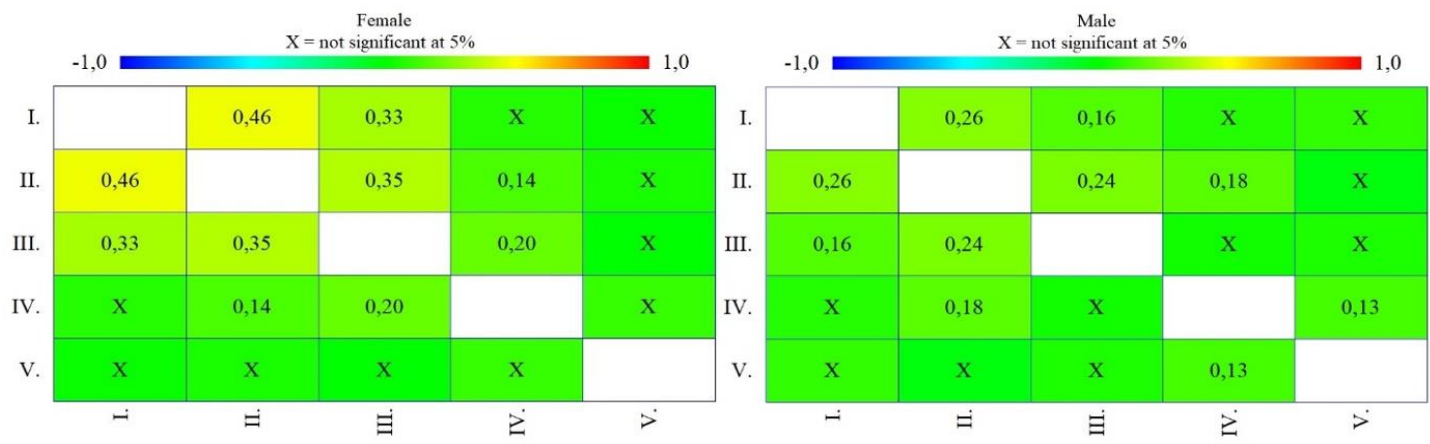

Figure 4. Rank linear correlation of the statements 


\section{CONCLUSION}

The survey showed negative and positive findings. Respondents, i.e. PU students in Prešov, negatively evaluated the existence of demand for sustainable tourism in the country in which they live (i.e. Slovakia). They understand sustainable tourism as a concept of traveling that meets the needs of today's tourists and preserves opportunities for future generations.

They consider the protection of monuments and the promotion of tourism to be mutually beneficial and are partly willing to financially support the development of sustainable tourism. Men are generally more negative towards the given statements, and the smallest difference can be observed especially in the willingness to financially contribute to the development of sustainable tourism. However, in case of women, if one attitude improves, it is possible to expect the improvement of evaluation of other observing aspects of sustainable tourism.

There are certain limitations that exist in the interpretation of results, for example, the research sample is represented by students from one university in Slovakia. This means that the results can be generalized only for the needs of this article, however in case of wanting to obtain objective results on the national level, it is necessary to conduct a similar survey at other universities across Slovakia. One of the solutions that could help achieving this comparison is the preparation and submission of a joint project focusing on sustainable development in Slovakia. Another dimension for research is cooperation with universities with similar field of study within Slovakia and comparison of the received results. The results could be used for a more specific survey, which would take into account the conclusions of a possible comparison of results at the level of university students in Slovakia (or university students studying within the economic field). Further use of these results can be found in the subsequent in-depth analysis of one of the evaluated areas. It is also possible to check other identification factors that could have a significant effect on the results obtained, e.g. place of residence or social status of the respondent.

\section{Acknowledgement}

This contribution presents some result from research project KEGA/No. 038PU-4/2018 "Development of Environmental Management Study Programme at the Second Level Study." The authors acknowledge to anonymous reviewers for their thoughtful suggestions and comments.

\section{REFERENCES}

Anděl, J. (2007). Základy matematické statistiky. [Basics of Mathematical Statistics], Matfyz, Prague, Czech Republic.

Black, R. (2012). Birth of the Green Generation, https://www.bbc.com/news/science-environment-18315205

Bramwell, B., \& Lane, B. (1993). Sustainable Tourism: An Evolving Global Approach. Journal of Sustainable Tourism, 1(1), 1-5. https://doi.org/doi: $10.1080 / 09669589309450696$

Budeanu, A. (2007). Sustainable Tourist Behaviour - a Discussion of Opportunities for Chance. International Journal of Consumer Behavior, 31,499-508. https://doi.org/10.1111/j.1470-6431.2007.00606.x

Butler, R.W. (1991). Tourism, Environment and Sustainable Development. Environmental Conservation, 18, 201-209. https://doi.org/10.1017/S0376892900022104

Cronin, L. (1990). A Strategy for Tourism and Sustainable Development. World Leisure and Recreation. 32(3), 12-18. https://5-594. https://doi.org/ $10.1080 / 09669580903524852$

Cyhelský, L., Kahounová, J., \& Hindls, R. (2001). Elementární statistická analýza. [Elementary Statistical Analysis], Management Press, Prague, Czech Republic.

Gallo, P.J., Mihalčová, B., Gallo, P., Jr., Čabinová, V., \& Tomčíková, L. (2019). Application of the balanced scorecard as a strategic management tool in practice: A case of Slovak tourism sector. Geojournal of Tourism and Geosites. 24(1), 19-28. https://doi.org/10.30892/gtg.24102-339

Hunter, C. (1997). Sustainable Tourism as an Adaptive Paradigm. Annals of Tourism Research. 24(4), 850-867. https://doi.org/10.1016/S0160-7383(97)00036-4

Huttmanová, E., Adamišin, P., \& Chovancová, J. (2013). Assessment of the current state of environment in the Slovak Republic with the use of green growth indicators. International Multidisciplinary Scientific GeoConference Surveying Geology and Mining Ecology Management, SGEM vol 1, pp. 133-140. https://doi.org/10.5593/SGEM2013/BE5.V1/S20.018

Ilieș, D.C., Baias, S., Buhaș, R., Ilieş, A., Herman G.V., Gaceu, O., Dumbrava, R. \& Maduta, F.M. (2017). Environmental Education in Protected Areas. Case study from Bihor County, Romania. GeoJournal of Tourism and Geosites, 19 (1), p. 126-132.

Ivaničková, M., Mihalčová, B. \& Gallo, P., (2016). Assessment of companies’ financial health: comparison of the selected prediction models. Actual problems of economics. $180(6), 383-391$

Krippendorf, J. (1987). Alpsegen, Alptraum. Für eine Tourismus-Entwicklung im Enklang mit Mensch und Natur.[Alpine Blessing, Nightmare. For Tourism Development in Harmony with People and Nature], Kümmerli, Bern, Switzerland.

Komppula, R., Honkanen, A. Rossi, S. \& Kolesnikova, N. (2018). The Impact of Values on Sustainable Behaviors - A Study among Russian and Finnish University Students. European Journal of Tourism Research, 19, 116-131, http://ejtr.vumk.eu/index.php/volume1/575-v19rp116

Miller, G. (2001). The Development of Indicators for Sustainable Tourism: results of a Delphi Survey of Tourism Researchers. Tourism Management, 22(4), 351-362. https://doi.org/10.1016/s0261-5177(00)00067-4

Pacáková, V., Vojtková, M., Šoltés, E., Sipková, L., \& Labudová, V. (2009). Štatistické metódy pre ekonómov. [Statistical Methods for Economists]. Iura Edition, Bratislava, Slovak Republic.

Pasquinelli, C., \& Trunfio, M. (2020). Overtouristified cities: an online news media narrative analysis. Journal of Sustainable Tourism, 28:11, 1805-1824, https://doi.org/10.1080/09669582.2020.1760871

Pigram, J. (1990). Sustainable Tourism - Policy Considerations. Journal of Tourism Studies. 1(2), 2-9.

Pulido-Fernandez, J.I., \& Lopéz-Sanchez, Y. (2016). Are Tourist Really Willing to Pay more for Sustainable Destinations. Sustainability. 8(12) 1240, https://doi.org/10.3390/su8121240

Ritchie, J. R.B., \& Crouch, G.I. (2003). The Competitive Destination: A Sustainability Perspective. CABI Publishing, Wallingford, UK.

Robinson, M., \& Picard, D. (2006). Tourism, Culture and Sustainable Development. Division of Cultural Policies and Intercultural Dialogue, Culture Sector, UNESCO. https://unesdoc.unesco.org/ark:/48223/pf0000147578

Swarbrooke, J. (1999). Sustainable Tourism Management. CABI Publishing, Wallingford, UK

Wehrli, R.H., Egli, M., Lutzenberger, D., Pfister, J. Schwarz, \& Stettler J. (2011). Is there De-mand for Sustainable Tourism? Study for the World Tourism Forum Lucerne, ITW Working Paper Series Tourism, 001/2011, Lucerne University of Applied Sciences and Arts.

Von Schirnding, Y. (2005). The World Summit on Sustainable Development: reaffirming the centrality of health. Global Health 1, 8. https://doi.org/10.1186/1744-8603-1-8

*** CVTI SR (2020). Prehl'ad vysokých škôl. [Overview of Universities in Slovakia]. https://www.cvtisr.sk/cvti-sr-vedecka-kniznica/informacie-o-skolstve/ publikacie-casopisy.../zistovanie-kvalifikovanosti/prehlad-vysokych-skol.html?page_id=9573 (in Slovak)

*** Statistical Office of the Slovak Republic, (2018). The Policy Context of the Agenda 2030. https://agenda2030.statistics.sk/Agenda2030/en/policy-context/

*** UNEP (2003). Tourism and Local Agenda 21. The Role of Local Authorities in Sustainable Tourism. http://www.unep.fr/shared/publications/pdf/3207TourismAgenda.pdf

*** United Nations Department of Economic and Social Affairs (2012). Synthesis of National Reports for Rio+20. https://sustainabledevelopment.un.org/content /documents/742RIO+20_Synthesis_Report_Final.pdf

*** United Nations Environment Programme and World Tourism Organization (2005). Making Tourism More Sustainable. A Guide for Policy Makers, Paris, France (UNEP), Madrid, Spain (WTO), dtix0592xpatourismpolicyen.pdf

*** United Nations (1987). Our Common Future. Report of the World Commission on Environment and Development. https://sustainabledevelopment.un.org/ content/documents/5987our-common-future.pdf

*** United Nations (2012). Report of the United Nations Conference on Sustainable Development. https://www.riob.org/fr/file/273754/download?token=nZIUIgRD

*** United Nations (2015). Transforming our world: The 2030 Agenda for Sustainable Development.https://sustainabledevelopment.un.org/content/documents/ $21252030 \% 20$ Agenda \%20for\%20Sustainable\%20Development\%20web.pdf 